patients with dissemination of virus and seriously ill patients with herpes zoster ophthalmicus need intravenous acyclovir. ${ }^{5}$ Possibly, the reversal of his immune-deficient state with stibogluconate resulted in the good recovery of our patient, even without treatment with acyclovir.

1 Straus SE, Ostrove JM, Inchauspe G, et al. Varicella-zoster virus infection: biology, natural history, treatment and vrevention. Ann Intern Med 1988;108:221-37.

2 Carvalho EM, Barral A, Pedral-Sampaio D, et al. Immuno2 Carvalho EM, Barral A, Pedral-Sampaio $\mathrm{D}$, et al. Immunologic markers of clinical evolution in children recently
infected with Leishmania donovani chagasi. $\mathcal{F}$ Infect Dis infected with Leish

3 Goffinet DR, Glastein EJ, Merigan TC. Herpes zostervaricella infections and Iymphoma. Ann Intern Med 1972;76:235-40.

4 Schimpff NJ, Serpick A, Stoler B, et al. Varicella zoster infection in patients with cancer. Ann Intern Med 1972;76: 241-54.

\section{Final diagnosis}

Extensive cephalic herpes zoster with ipsilateral cerebellar involvement in a patient with visceral leishmaniasis.

Keywords: leishmaniasis; herpes zoster

5 Fauci AS, Lane HC. Human immuno-deficiency virus (HIV) disease: AIDS and related disorders. In: Isselbacher KT, Braunwald E, Wilson JD, et al eds, Harrison's Principles of internal medicine, 15th edn, Vol II. New York: McGrawof internal medicine, 15th

6 Snow BJ, Simcock JP. Brainstem infarction following cervical herpes zoster. Neurology 1988;38:131.

7 Leinneman CC, Alvira MM. Pathogenesis of VZ angiitis in the CNS. Arch Neurol 1980;37:239-40.

8 Reshef E, Greenberg SB, Jankovic J. Herpes zoster ophthalmicus followed by contra lateral hemiparesis. Report of two cases and review of literature. $\mathcal{F}$ Neurol Neurosurg Psychiatry $1985 ; 48: 122-7$.

\title{
Abdominal pain in a patient with falciparum malaria
}

\author{
P S A Sarma, R Shashi Kumar
}

A 17-year-old native Central Indian man was hospitalised with constant abdominal pain accompanied by fever, chill, sweats and vomiting of 4 days duration. He was unemployed, and did not use tobacco, alcohol or illicit drugs. There was no history of biliary tract disease or lipid disorders, malaria or use of steroids or antimalarial drugs. On examination, he was found to be alert, febrile $\left(38^{\circ} \mathrm{C}\right)$, jaundiced, and normotensive. Epigastric tenderness and mild generalised abdominal distension with reduced intestinal peristaltic sounds were noted. Laboratory studies showed: haemoglobin $9.8 \mathrm{~g} / \mathrm{dl}$, leucocyte count $11.8 \times 10^{9} / 1$ (polymorphs $73 \%$ ), erythrocyte sedimentation rate $28 \mathrm{~mm} / \mathrm{h}$, and haematocrit $29 \%$. Blood urea nitrogen was $7.2 \mathrm{mmol} / \mathrm{l}$, creatinine $145 \mu \mathrm{mol} / \mathrm{l}$, and serum electrolytes, cholesterol, and triglycerides were normal. Liver function tests showed a total bilirubin value of $31 \mu \mathrm{mol} / 1$, and minimally raised hepatic enzymes (aspartate aminotrans-

Department of Medicine, Jawaharlal Nehru Hospital and Research Centre, Bhilainagar, Madhya Pradesh 490006, India P S A Sarma

R S Kumar

Correspondence to Dr P S A Sarma, MIG II - 437, Hudco, Amdinagar Bhilainagar, Madhya Pradesh, PIN 490006, India

Accepted 21 January 1998 ferase $84 \mathrm{U} / \mathrm{l}$, alanine aminotransferase $70 \mathrm{U} / \mathrm{l})$. Hyperamylasaemia $(2132 \mathrm{U} / \mathrm{l})$, hypocalcaemia $(1.9 \mathrm{mmol} / \mathrm{l})$, and hypoalbuminaemia $(32 \mathrm{~g} / \mathrm{l})$ were detected. Urinary amylase levels were raised to $4011 \mathrm{U} / 1$. A Leishman-stained peripheral blood smear demonstrated several ring-form trophozoites of Plasmodium falciparum (1.5\% of parasitaemia). The electrocardiogram showed normal sinus rhythm. The red blood sickling, and antinuclear antibody tests were negative. An abdominal X-ray showed mild generalised ileus without air-fluid levels. Ultrasound demonstrated an oedematous, enlarged pancreas.

\section{Questions}

1 What is the most likely diagnosis?

2 How does abdominal pain manifest in falciparum malaria?

3 List the infectious causes of acute pancreatitis. 


\section{Answers}

QUESTION 1

Acute pancreatitis due to falciparum malaria The condition is characterised by severe pain in the upper abdomen and elevation of serum amylase. The diagnosis was supported by characteristic findings at abdominal ultrasonography and computed tomography of the abdomen which showed pancreatic oedema. ${ }^{1}$

\section{QUESTION 2}

Abdominal pain occurs in acute falciparum malaria, a great mimic of other diseases, as one of the localised symptoms with or without chest pain and arthralgias, as a component of the symptom complex of algid malaria and acute renal failure, ${ }^{2}$ and rarely as a presenting manifestation of acute pancreatitis ${ }^{34}$ (box 1).

\section{QUESTION 3}

Various infectious agents have been incriminated as aetiologic agents of acute pancreatitis. However, pancreatitis due to $P$ falciparum is rarely encountered ${ }^{34}$ (box 2 ).

\section{Outcome}

The patient was treated conservatively with quinine, intravenous fluids, fasting, nasogastric suction, antibiotics, $\mathrm{H}_{2}$-blockers, analgesics,

\section{Causes of abdominal pain in falciparum malaria}

- localised symptom with or without chest pain and arthralgias

- component of symptom complex of algid malaria

- component of symptom complex of acute renal failure

- presenting manifestation of acute pancreatitis (rare)

Box 1

$$
\begin{aligned}
& \text { Infectious aetiology of acute } \\
& \text { pancreatitis } \\
& \hline \text { Viral } \\
& \text { - mumps, hepatitis virus, coxsackie, Epstein-Barr, } \\
& \text { cytomegalovirus } \\
& \text { - after immunisation with measles, mumps and } \\
& \text { rubella attenuated vaccine } \\
& \text { Mycobacterial } \\
& \text { - M tuberculosis, M avium-intracellulare } \\
& \text { Bacterial } \\
& \text { - leptospira, Salmonella tophi, mycoplasma, } \\
& \text { Staphylococcus aureus } \\
& \text { Fungal } \\
& \text { - Aspergillus spp, Candida spp, Cryptococcus } \\
& \text { neoformans, Pneumocystis carinii } \\
& \text { Parasitic } \\
& \text { - Opisthorchis sinensis, Ascaris lumbricoides } \\
& \text { - Toxoplasma gondii, cryptosporidium, } \\
& \text { microsporidium, Plasmodium falciparum }
\end{aligned}
$$

and antacids. Over the next four days, he became afebrile, and anicteric; tenderness and distension of the abdomen decreased and vomiting stopped; the urinary amylase level decreased to $2411 \mathrm{U} / 1$. On the fifth hospital day, clear liquids were begun by mouth. Ultrasound performed on the day of discharge (seventh hospital day) showed a marked decrease in pancreatic oedema.

Twenty-one days after hospitalisation, during follow-up examination, repeat ultrasound and CT scan showed a normal pancreas. The peripheral blood smear was negative for malarial parasite; serum albumin rose to $38 \mathrm{~g} / \mathrm{l}$, and calcium to $2.3 \mathrm{mmol} / \mathrm{l}$. Blood haemoglobin, urea nitrogen, creatinine, bilirubin, and hepatic enzymes returned to normal values. The serum and urinary amylase levels were normalised. The patient is well two months after discharge.

\section{Discussion}

From mild disease to multi-organ failure and sepsis, acute pancreatitis is a disorder that has numerous causes, an obscure pathogenesis, few effective remedies, and an often unpredictable outcome. ${ }^{5}$ Falciparum malaria causes many different syndromes. ${ }^{6}$ Abdominal pain occurs in falciparum malaria as a presenting manifestation of acute pancreatitis.

Acute pancreatitis as a complication of falciparum malaria has been reported infrequently in the English literature. ${ }^{34}$ Pancreatitis occurring in $P$ falciparum infection was not mentioned in a recent review of pancreatitis, ${ }^{5}$ or in an exhaustive list of aetiological agents of pancreatitis. ${ }^{1}$ At least some of the current major medical texts, ${ }^{7-9}$ do not include $P$ falciparum as an aetiological agent of pancreatitis.

The accumulation of parasitized erythrocytes (occasionally causing thrombosis and infarcts) is more common in the small vessels of the spleen, liver, bone marrow, and brain, than in the kidneys, small intestine, pancreas, heart and lungs. ${ }^{10}$ However, the erythrocytic part of the life-cycle of $P$ falciparum, known as sporogony, occurs in the deep visceral capillaries throughout the body. ${ }^{81112}$

In fatal $P$ falciparum infection, autopsy studies demonstrated that the small blood vessels of the pancreas were packed with parasitized red cells and rosettes. ${ }^{13}$ The parasitized erythrocytes bind to receptors on the endothelial cells by the formation of knobs (electron-dense structures), ${ }^{72}$ and cause obstruction of capillary blood flow. ${ }^{711}$ Tumour necrosis factor released from macrophages may be directly toxic to endothelial cells, favouring the accretion of thrombin, which may make the endothelial cells more adhesive for the surface of parasitized erythrocytes. ${ }^{14}$ These vascular changes lead to anoxic damage to diverse organs, thus accounting for the protean clinical manifestations of falciparum malaria. ${ }^{12}$

This case report presents a patient with confirmed pancreatitis in the setting of acute falciparum malaria. While acute pancreatitis might be a rare cause of abdominal pain and vomiting in $P$ falciparum infection, its serology is routine. 


\section{Summary / learning points}

- acute pancreatitis can occur as a complication of falciparum malaria

- persistent and severe abdominal pain may be presenting manifestation of acute pancreatitis in $P$ falciparum infection

- serology of pancreatitis should be ordered routinely in falciparum malaria

- pancreatitis should be considered in the spectrum of disease associated with $P$ falciparum infection

Box 3
The list of identifiable causes of pancreatitis is growing and pancreatitis should be considered in the spectrum of disease associated with $P$ falciparum infection.

\section{Final diagnosis}

Acute pancreatitis complicating falciparum malaria.

Keywords: acute pancreatitis; malaria; Plasmodium falciparum
1 Banks PA. Acute pancreatitis. In: Haibrich WS, Schaffner F, Berk JE, eds. Bockus Gastroenterology, 5th edn. Philadephia: WB Saunders Company, 1995; pp 2888-917.

2 Case records of the Massachusetts General Hospital (case 35-1989). N Engl f Med 1989;321:597-605.

3 Sheehey TW, Reba RC. Complications of falciparum malaria and their treatment. Ann Intern Med 1967;66:8079 .

4 Gurman G, Schlaeffer F, Alkan M, Heilig I. Adult respiratory distress syndrome and pancreatitis as complications of falciparum malaria. Crit Care Med 1988;16:205-6. 5 Steinberg W, Tenner S. Acute pancreatitis. $N$ Engl f Med 1994;330:1198-1210.

6 World Health Organization. Severe and complicated malaria. Trans $R$ Soc Trop Med Hyg 1990;84 (suppl 2):1-65.

7 White NJ, Breman JG. Malaria and babesiosis. In: Isselbacher $\mathrm{KJ}$, Braunwald $\mathrm{E}$, Wilson $\mathrm{JD}$, et al, eds. Harrison's Principles and practice of medicine, 13th edn. New York: McGraw Hill Inc, 1994;

8 Krogsted DJ. Plasmodium species (malaria). In: Mandell GL, Bennet JE, Dolin R, eds, Principles and practice of infectious diseases. 4th edn. New York: Churchill Livingstone, 1995; pp 2415-7.
9 Bradley D, Newbold CI, Warrell DA. Malaria. In: Weatherall DJ, Ledingham TG, Warrell DA, eds. Oxford: Oxford University Press, 1996; pp 835-63.

10 Marcial MA, Marcial-Rojas RA. Protozoal and helminthic infections. In: Kissane JM, ed. Anderson's Pathology, 9th edn. St Louis: CV Mosby Company, 1990; pp 205-6

11 Boonpucknavig V, Boonbpucknavig S. The histopathology of malaria. In: Wersdorfer WH, Mc Cregor IA, eds. The principles and practice of malariology. Edinburgh: Churchill pivingstone, 1988; pp 673-734.

12 Lichtman AR, Mohracken S, Englebrecht M, Bigalke M. Pathophysiology of severe forms of falciparum malaria. Crit Care Med 1990;16:205-6.

13 White NJ, Ho M. The pathophysiology of malaria. Adv Parasitol 1992;31:34-173.

14 Clark IA. Monokines and Iymphokines in malarial pathology. Ann Trop Med Parasitol 1987;577-85.

\title{
Metabolic acidosis
}

\author{
M Souheil Darwich, Waddah Allaf
}

\section{Department of Medicine, Wright State University, Good Samaritan Hospital and Health Center, 3535 Salem Ave, Dayton, OH 45406, USA M S Darwich}

50 Gibson Blvd, Apt\# B7, Valley Stream, NY 11581 , USA

W Allaf

Accepted 21 January 1998
A 60 -year-old woman on haemodialysis secondary to end-stage renal disease, was brought to the emergency room with recent onset of weakness, decreased consciousness and shortness of breath. She has a history of diabetes mellitus, hypertension and coronary artery disease.

Her medications on admission to the emergency room were: hydralazine, quinidine sulphate, catapress patch, lorazepam, dipyridamol, propulsid, nifidepine $\mathrm{XL}$, metformin $\mathrm{HCl}$, promethazine, and zolpidem tartrate. Physical examination revealed the following: respiratory rate 26 breaths/min and shallow, pulse 104 , blood pressure $120 / 70 \mathrm{mmHg}$, afebrile. Physical examination was otherwise remarkable for only mild abdominal tenderness. Laboratory investigation revealed: sodium $141 \mathrm{mmol} / 1, \mathrm{HCO}_{3} 9 \mathrm{mmol} / \mathrm{l}$, blood urea nitrogen $36 \mathrm{mg} / \mathrm{dl}$, creatinine $9.7 \mu \mathrm{mol} / \mathrm{l}$, glucose $172 \mathrm{mmol} / \mathrm{l}$, amylase $168 \mathrm{mmol} / \mathrm{l}$, alanine transaminase $19 \mathrm{IU} / \mathrm{l}$, serum ketones $1: 4$ dilution, lactic acid $17.4 \mathrm{mmol} / \mathrm{l}$; whole blood count was normal. Arterial blood gas: $\mathrm{pH} 6.88, \mathrm{pCO}_{2} 9.5, \mathrm{pO}_{2}$ $153, \mathrm{HCO}_{3} 1.8, \mathrm{SaO}_{2} 97.2$ on room air.

During her stay in the emergency room, the patient became more lethargic and tachypnoeic, eventually requiring intubation and mechanical ventilation.

\section{Question}

What is the most likely diagnosis: sepsis, diabetic ketoacidosis, drug-related side-effect, uraemic acidosis, or salicylate overdose? 